\title{
AN ANALYSIS OF THE IMPACT OF SELECTED FACTORS ON THE BOND MARKET
}

\author{
Blanka Francová ${ }^{1}$ \\ ${ }^{1}$ Department of Economics, Faculty of Business and Economics, Mendel University in Brno, Zemědělska 1, 61300 \\ Brno, Czech Republic
}

To cite this article: FRANCOVÁ BLANKA. 2018. An Analysis of the Impact of Selected Factors on the Bond Market. Acta Universitatis Agriculturae et Silviculturae Mendelianae Brunensis, 66(6): 1451-1458.

To link to this article: https://doi.org/10.11118/actaun201866061451

\begin{abstract}
Exchange rate risk is important factor for the valuation of capital asset on international markets. According to the International Arbitrage Pricing Theory currency movements affect the prices of capital assets and associated risk premiums. The International Arbitrage Pricing Theory is based on total return of asset decomposition to non-currency return and currency return. The currency return is defined by exchange rate risk and the non-currency return is defined by factors affecting the price of capital assets. We propose an empirical model to apply this theory using corporate bonds. Using a rich dataset from Morningstar in the period 2001-2017 we employ the linear regression analysis method OLS with fixed effects. We apply the model for different bond yields and different time-series. The factors influence bond price differently for each yield and each time-series. Our results confirm that currency movements significantly affect the bond prices.
\end{abstract}

Keywords: pricing bonds, exchange rate, interest rate, inflation

\section{INTRODUCTION}

For the valuation of bonds is important to investigate the role of macroeconomic and financial indicators. The investment decision is mostly affected by the macroeconomic condition in the country. Investors should understand the impact of macroeconomic variables on an investment asset. Several asset pricing models emphasise the role of fundamentals in the dynamics of risk and return. The result, how economic variables and macroeconomic indicators signal the dynamics of bond return, is still a question of interest.

The aim of our research is to investigate the impact of macroeconomic and market factors on bond return by examining this question in respect of one large developed country, the USA, as one of the largest financial markets in the world. The analysis of the impact of selected factors is for three types of bond return: yield to maturity, current yield and capital yield. Each yield is specific, and the factors effect yield differently. Macroeconomic and financial indicators each have a different impact on each bond. Particular attention will be paid to yield to maturity as it includes both capital yield and current yield. The analysis of impact of selected factors will be for three time-series: before the crisis, during the crisis and after the crisis. This paper shows impact of the factors on bond price for different bond yields and different times.

Our study builds on the capital asset pricing literature. Interest rates and inflation influence bond returns (Huang and Kong, 2002; Elton, 2004; Chao, 2016). Nominal bond yields have been constrained by the interest rate lower bound (Rezende, 2017). During the financial crisis of 2008 and the following years, many central banks reduced their target interest rates as a traditional tool of monetary policy. Interest rates were at their lower limit. Monetary policies have helped to reduce long-term interest rates (Christensen and Rudebusch, 2012; Sirr et al., 
2011) and deflationary pressures. The central banks may keep policy rates low for a longer time. The central banks may be able to affect bond yields by changing risk premiums (Rezende, 2017).

In his work, Elton (2004) defined the bond factors affecting bond prices for several characteristics of bonds within a rating class into groups. The model used for the valuation of bonds considers the absence of arbitrage and the existence of zero risk. The model is suitable for homogeneous bonds. Huang and Kong (2002) used market specification and the equity market for the valuation of bonds. Shih-Wei Chao (2016) explored various macroeconomic variables and bond returns. Some economic variables are conducive to bond return volatility prediction. The forecasting ability is particularly evident at the short end of the term structure. Ludvigson and Ng (2009) study a comprehensive list of macroeconomic variables and find that inflation has important forecasting power for US bond risk premiums.

Asset pricing models predict that the expected return on an asset will equal the sum of the premiums of systematic risk and the price of risk from this asset. According to these models, the time variation in expected bond returns must be the result of time variation in the aggregate price of risk or the quantity of bond risk.

Huang and Kong (2002) used model prices of corporate bonds. They apply an empirical model for pricing corporate bonds. Moreover, the authors used the Fama-French high-minus-low factor in the equity market. High-yield bonds are more closely related with interest rate and equity market factors. Brennan (2001) applies intertemporal asset pricing and the Fama-French portfolio. The Fama-French model has been found to be associated with HML and SMB portfolio returns. The Fama-French portfolio does predict the real interest rate and the Sharpe ratio. Investors diversify their portfolios across international markets. Exchange rate risks affect the returns on international investments (Sirr, 2011; Liu, 2012; Panda, 2013).

The Capital Asset Pricing Model (CAPM) is an attractive and simple model for pricing of capital asset by domestic investors. The model performs the covariance of asset returns with risk-free rate and market portfolio. Viceira (2011) realised CAPM for bond markets. The assumption of the Capital Asset Pricing Model is am identified market portfolio. The International Capital Asset Pricing Model (ICAPM) was applied by Solnik (1974), Sercu (1980). Exchange rate risk has traditionally been specified as separate factor affecting the prices of capital assets. The market portfolio does not exist in the international framework. The Arbitrage Pricing Theory (APT) provides a fruitful alternative to these utility-based models. APT risk factors should explain the variation of returns of capital assets. (Brennan, 1998). The International Arbitrage Pricing Theory (IAPT), formulated by Solnik (1983), is a multi-consumption real Capital Asset Pricing
Model. The form of the international arbitrage pricing theory model is unchanged by investors with different home currencies. The main assumptions of IAPT are purchasing power parity, efficient markets and the possibility of arbitrage.

Solnik (1983) was the first to apply international arbitrage pricing theory. The form of the international arbitrage pricing theory model is unchanged by investors with different home currencies, while risk premiums are highly dependent on the investor's home currency. International asset pricing theory decomposes asset returns into portions due to currency returns and non-currency returns. Armstrong (2012) defined changes in underlying asset values (non-currency) and random currency movements (i.e., exchange rate risk). Non-currency returns are earned by all investors regardless of their home currency. The exchange risk is associated with random changes in currency values and changes in the asset returns of investors with different home currencies. Currency movements affect risk factors and additional residual exchange risk. The main assumptions of international asset pricing theory are purchasing power parity, efficient markets and the possibility of arbitrage. Arbitrage pricing theory has been applied for various commodities and markets (Malhotra, 2010; Middleton, 2001; Geambasu, 2014; Cho, 1986).

We apply this universal return decomposition to Solnik's (1983) International Arbitrage Pricing Theory for corporate bonds. This theory decomposes asset returns into returns on movements of prices and returns of movements of currency. The basis of this theory is the capital pricing model.

In this paper we seek to contribute to the literature by testing the International Arbitrage Pricing Theory proposition that currency movements affect systematic risk factors themselves in addition to residual exchange rate risk.

Results tend to confirm that the interest rate does not affect bond prices in times with low inflation and low interest rates. The interest rate has a negative effect on bond prices. The exchange rate is an important factor for valuing bonds.

The rest of the article is structured as follows: Section 2 discusses the data and methodology used to measure factors affecting bond returns. Section 3 displays the results and Section 4 the conclusion.

\section{MATERIALS AND METHODS}

The U.S. bond market is $42.66 \%$ of the world bond market making it the biggest in the world. Corporate bonds account for $85 \%$ of the U.S. bond market. The corporate bonds are the largest part of bond market. Our panel on the U.S. companies issuing corporate bonds includes a rich dataset of 71195 corporate bonds in the U.S. market. We mostly focus on factors affecting the current bond yield, capital bond yield and bond yield to maturity. The bond return is influenced by the risk premium. 
We consider several bond-specific variables which describe asset quality: current yield, capital yield, yield to maturity and currency of issue. We merge the bond prices with a macroeconomic data set: inflation, interest rate and exchange rate. The predictability of bond risk premiums also motivates the use of these macroeconomic variables. The bond prices are influenced by local market factors: risk-free rate, bond yield, bond index and stock index. The treasury yield is the risk-free rate. All of the forecasting variables are sampled monthly.

Our monthly panel data set covers the period from January 2001 to November 2017. This period is made up of the time before the crisis, the time during the crisis and the time with low interest rates and low inflation after the crisis. This dataset includes data on companies in the USA. Our macroeconomic data on the USA are from the International Monetary Fund and the World Bank. The local market variables are from Finance Yahoo. Our information about corporate bonds is from the Morningstar database.

Taking all the restrictions of the different data sources into account we end up with a dataset that contains over 850,000 observations for the USA available for the estimations. A detailed description of the data and our sources is given in the Appendix.

Using this panel data set, we focus on the impact of factors on corporate bond $i$ in time $t$, with the cross-sectional dimension and the number of time periods. We use the model of international arbitrage pricing theory. The baseline estimation is specified as:

returns $_{i t}=\alpha_{i t}+r f_{c t}+\beta_{b} b v_{i t}+\sum_{m=1}^{M} \beta_{m} m v_{c t}+\sum_{f=1}^{F} \beta_{f} f v_{c t}+\mu_{i}+\varepsilon_{i t}$

where returns $s_{\text {it }}$ is the returns of a corporate bond $i$ in time $t, \alpha_{i t}$ is a constant for $i$ corporate bonds in time $t, r f_{t}$ is the risk-free return in time $t$. The second variable $b v_{i}$, denoted variables of corporate bonds $i$, represented currency in which is the bond issued. The next set of variables $m v_{c t}$, denoting macroeconomic variables in a country $c$, includes inflation, the interest rate and the exchange rate. The next set of variables $f v_{c t}$ is financial market variables in a country $c$ as the risk-free rate, bond yield, bond index and stock index. And $\varepsilon_{i t}$.is possibly heteroscedastic residual. This model is applied for OLS regression with a fixed effect estimator. In the robustness analysis we divided the dataset into shorter times.

It is appropriate to mention that the variables bond index and stock index are intended for application on first difference of logarithmic values, and other variables money market interest rate, consumer price index, bond yield and NEER are intended for the first difference.

\section{RESULTS}

This section presents the results for the impact of factors on the returns of corporate bonds. We apply

I: The main result

(1)

VARIABLES

\begin{tabular}{|c|c|c|c|}
\hline VARIABLES & Macroeconomic variables & Market specific variables & All variables \\
\hline \multirow[t]{2}{*}{ Risk-free rate } & & $0.5017^{* * *}$ & $0.5131^{* * *}$ \\
\hline & & $(0.0054)$ & $(0.0056)$ \\
\hline \multirow[t]{2}{*}{ Money market rate } & $-2.0369 * * *$ & & $-2.0864 * * *$ \\
\hline & (0.0294) & & $(0.0300)$ \\
\hline \multirow[t]{2}{*}{ Consumer price index } & $0.1289 * * *$ & & $0.1541^{* * *}$ \\
\hline & $(0.0102)$ & & $(0.0107)$ \\
\hline \multirow[t]{2}{*}{ NEER } & $-0.0317 * * *$ & & $0.0164 * * *$ \\
\hline & $(0.0023)$ & & $(0.0025)$ \\
\hline \multirow[t]{2}{*}{ Bond yield } & & $-0.1996^{* * *}$ & $-0.2122 * * *$ \\
\hline & & $(0.0187)$ & (0.0194) \\
\hline \multirow[t]{2}{*}{ Stock index } & & $-0.0016^{* * *}$ & $-0.0009 * * *$ \\
\hline & & $(0.0001)$ & $(0.0001)$ \\
\hline \multirow[t]{2}{*}{ Bond index } & & $-0.0116^{* * *}$ & 0.0002 \\
\hline & & $(0.0016)$ & $(0.0016)$ \\
\hline \multirow[t]{2}{*}{ Constant } & $5.8045^{* * *}$ & $4.1882^{* * *}$ & $4.0852 * * *$ \\
\hline & $(0.0041)$ & $(0.0183)$ & $(0.0193)$ \\
\hline Observations & 863,210 & 843,137 & 843,024 \\
\hline R-squared & 0.007 & 0.036 & 0.039 \\
\hline F-statistics & $1664.86^{* * *}$ & $2294.26^{* * *}$ & $2010.88^{* * *}$ \\
\hline Number of bonds & 18,886 & 18,424 & 18,420 \\
\hline
\end{tabular}

OLS with fixed effects. Standard errors in parentheses. ${ }^{* * *} \mathrm{p}<0.01,{ }^{* *} \mathrm{p}<0.05, * \mathrm{p}<0.1$. 
regression analyses for monthly periods from 2001 to 2017. We present the results for OLS methods with fixed effects for panel regression analysis. The results of the Hausman test are given in Tab. VII in the Appendix.

We start our analysis with the examination of lending determinants without considering bond yield type. Tab. I presents the results of the first three models that vary according to the inclusion of macroeconomic variables, specific market variables and all variables. The bond return is the yield to maturity for these three models. The first model (1) includes only macroeconomic variables (interest rate, inflation and exchange rate). Our results show that the interest rate tends to slow down bond yield, possibly through a reduction of bond yields. Inflation has an important forecasting power for bond risk premium. The consumer price index includes expected and unexpected inflation. If the expected influence raises, the investors want to compose a lower real return and the bond yield raises. Appreciates of currency in which the bond was issued decreases yield of bonds. If the nominal exchange rate effect increases, the national currency depreciates.

The second model (2) includes only market specific variables (risk-free rate, bond yield, bond index and stock index). These variables are significant. The risk-free rate is the basis of the asset return. Further factors represent the risk premium. The long-term bond yield has a negative impact on bond price, when the bond yield declines, the price of the issued bond increases. The impact of the stock index on the bond yield is negative. If the stock prices decrease, then investors invest into bonds.

The third model (3) includes all the variables. Models do not respond by changing most coefficient estimates after adding additional variables. The models are stable and correctly capture the causality between the variables. The significance of differences in interest rates appears to reflect the role of monetary policy in determining bond return. These results imply that volatility in these macroeconomic variables could also forecast bond return.

At the next step, we can decompose yield to maturity into capital yield and current yield. The current yield is the yield of coupon payment. The capital yield is set by movement of bond prices on the capital market. Selected factors each affect the return differently. Tab. II includes results of types of bond yield.

Most of the variables are highly significant. The risk-free rate affects the capital yield more than the current yield. The bond price is dependent on risk premium and risk-free return in accordance with the Arbitrage Pricing Theory (Armstrong, 2012). The risk-free return is the minimum return on investment that investors demand. The risk-free return is given by the risk-free rate. The impact of the risk-free rate of return of securities is in positive accordance with the APT. The interest rate influences current yield more than capital yield.

II: The results for types of bond yield

(4)

\begin{tabular}{lccc}
\multicolumn{1}{c}{ VARIABLES } & Yield to maturity & Current yield & Capital yield \\
\hline Risk-free rate & $0.5131^{* * *}$ & $0.1551^{* * *}$ & $0.3224^{* * *}$ \\
Money market rate & $(0.0056)$ & $(0.0086)$ & $(0.0031)$ \\
\hline Consumer price index & $-2.0864^{* * *}$ & $-0.9253^{* * *}$ & $-0.4651^{* * *}$ \\
& $(0.0300)$ & $(0.0436)$ & $(0.0159)$ \\
NEER & $0.1541^{* * *}$ & $0.0709 * * *$ & $0.0482^{* * *}$ \\
& $(0.0107)$ & $(0.0147)$ & $(0.0054)$ \\
Bond yield & $0.0164^{* * *}$ & $0.0188^{* * *}$ & $-0.0039^{* * *}$ \\
& $(0.0025)$ & $(0.0034)$ & $(0.0013)$ \\
Stock index & $-0.2122^{* * *}$ & $-0.1624 * * *$ & $-0.0924^{* * *}$ \\
& $(0.0194)$ & $(0.0267)$ & $(0.0098)$ \\
Bond index & $-0.0009^{* * *}$ & $-0.0002^{*}$ & $-0.0004^{* * *}$ \\
& $(0.0001)$ & $(0.0001)$ & $(0.0001)$ \\
Constant & 0.0002 & 0.0009 & -0.0008 \\
& $(0.0016)$ & $(0.0022)$ & $(0.0008)$ \\
\hline Observations & $4.0852^{* * *}$ & $5.3956^{* * *}$ & $-1.2943^{* * *}$ \\
R-squared & $(0.0193)$ & $(0.0289)$ & $(0.0106)$ \\
F-statistics & 843,024 & 662,843 & 642,161 \\
Number of bonds & 0.039 & 0.012 & 0.002 \\
\hline OLSwith & $2010.88^{* * *}$ & $112.70^{* * *}$ & $1730.02 * * *$ \\
\end{tabular}

OLS with fixed effects. Standard errors in parentheses. ${ }^{* * *} \mathrm{p}<0.01,{ }^{* *} \mathrm{p}<0.05,{ }^{*} \mathrm{p}<0.1$. 
The coupon yield is dependent on the interest rate. If the interest rate increases, new bonds will be issued with a higher yield. The bonds issued in the past will have a lower yield than bonds now being issued so these bonds' prices decline. The impact of exchange rate on current yield is positive. If currency in which the bond was issued appreciates, the coupon payments are paid in this currency and foreign investors can exchange payments for a more favourable exchange rate for them. The impact of exchange rate on capital yield is negative. The capital yield is formed on the bond market due to price movements. If currency in which the bond was issued appreciates, foreign investors must spend more money in their currency to buy these bonds. The bonds become more expensive and the demand for them decreases. The impact of the stock index is negative for all types of bond yield. The bond index is not significant for all types of bond yield.

Because the yield to maturity includes the current yield and capital yield, for the next analyses we use yield to maturity. The total bond return is used by Viceira (2012) for the valuation of bonds. Because the significance of forecasting variables might change over time, the predictive regressions are also estimated for three shorter horizons. We define three periods. The first one covers from 2001 to 2006, which includes time before the crisis in model 7 . The subsequent 2007-2009 period represents the crisis in model 8, and 2010-2017 represents the period after the crisis in model 9 and this is typical for a time of low inflation and low interest rates. The results for these periods are presented in Tab. III.

During the crisis, the impact of the risk-free rate on bond price was negative. In this period, investors preferred to buy safe assets as a term-deposit for a risk-free rate. The interest rate is not significant in periods with low inflation and low interest rates. The interest rate was around the zero bound and consistent. If the interest rate is low it does not have an impact on bond prices. The impact of inflation is negative in the periods before and after the crisis. Inflation reduces the real return of bonds. In the crisis the impact of inflation on bond price was positive. In a time of recession, inflation represents the stability of the financial markets and of the whole country. If inflation increases in a time of recession the stability of the country decreases. The investor will require higher bond returns as compensation for the additional risk. The bond prices must thus increase. The exchange rate is significant with a positive impact for the pre-crisis and post-crisis periods. In the pre-crisis period the exchange rate showed stability in the country. The appreciating currency implied a booming economy, and investors expected security and stability of their investment return. In times with low interest rates and low bond yields investors buy bonds with a different target than obtaining a bond yield - for example for currency yield. The bond yield is not significant for the post-crisis period, like the interest rate. The impact of stock index

III: Result for periods before crisis, during crisis and after crisis

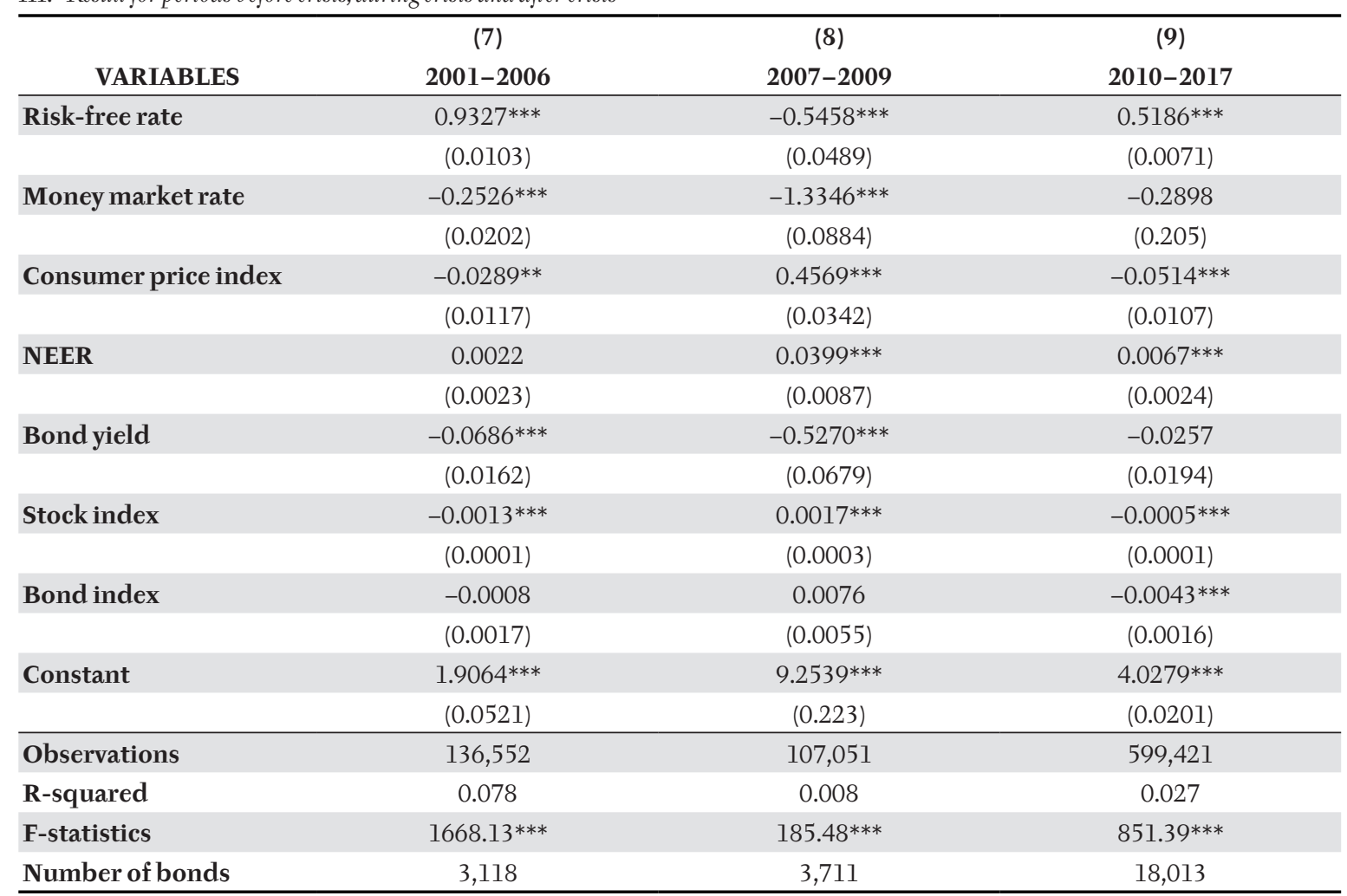

OLS with fixed effects. Standard errors in parentheses. ${ }^{* * *} \mathrm{p}<0.01,{ }^{* *} \mathrm{p}<0.05,{ }^{*} \mathrm{p}<0.1$ 
on bond price is positive in the pre-crisis period. The capital markets were distrusted at the time of the crisis and investors were cautious. The stock index reflects the situation on all the capital market. In the time of crisis, if stock index was successful on the capital markets, it was also in confidence in bond instruments. Investors often move from risky assets to securities with little default risk during a financial crisis. The bond index is significant with a negative impact for the post-crisis period.

\section{CONCLUSION}

This paper has attempted an empirical investigation of how Armstrong (2012) tested the International Arbitrage Pricing Theory proposition that home currency movements affect the factor loadings and risk premiums of bond prices. To do this, we used bond returns decomposed into portions or asset returns and currency returns. The asset returns are earned by all investors regardless of their home currency. The currency returns are earned by investors with different home currencies. We apply the International Arbitrage Pricing Model for monthly returns on corporate bonds on the U.S. market for the period 2001-2017. For this purpose we utilised the home-currency to currency index (NEER) exchange rates. The total exchange rate risk of bonds is composed of the exchange rate risk containing the currency risk for the issue. The home currency movements are priced into the market factor.

The model was applied for yield to maturity, current yield and capital yield. The selected factors influence on current and capital yield different. For the current yield the interest rate is more significant. The current yield is coupon payments that are determined by the interest rate. For the capital yield the risk-free rate is more significant when the bond price is influenced by risk-free rate and risk premium in accordance with the Arbitrage Pricing Theory. The exchange rate risk affects current yield and capital yield differently. The results show the impact of factors on bond prices for the crisis, pre-crisis and after crisis periods. The bond prices behave differently in times of crisis and in times with low interest rates. For valuation of bonds the times in which the valuation is performed are important. At a time of low interest rate and inflation, the interest rate plays no role in the valuation of bonds. And at a time of crisis, the risk-free rate and inflation behave differently for the valuation of bonds than in other periods.

Using the yield to maturity of corporate bonds for the 2001-2017 period this study investigates whether including various economic variables in predictive regressions improves the forecasts for the monthly U.S. bond return. We contribute to the literature on bond return forecast ability by showing that macroeconomic fundamentals have an important predictive power for returns on U.S. corporate bonds. The forecasting ability is particularly evident in historical periods. According to the above analysis, some economic variables are conducive to bond return prediction. The data supports a predictive relationship between bond yields and several economic variables in a certain historical period - economists and experts might be interested in whether this relationship is still valid in the future.

Acknowledgements

This research was funded by the Czech Science Foundation, grant No. 16-26353S "Sentiment and its Impact on Stock Markets".

\section{REFERENCES}

ARMSTRONG, W. J., KNIF, J., KOLARI, J. W. and PYNNÖNEN, S. 2012. Exchange risk and universal returns: A test of international arbitrage pricing theory. Pacific-Basin Finance Journal, 20(1): 24-40.

BRENNAN, M. J., CHORDIA, T. and SUBRAHMANYAM, A. 1998. Alternative factor specifications, security characteristics, and the cross-section of expected stock returns. Journal of Financial Economics, 49(3): 345-373.

ELTON, E. J., GRUBER, M. J., AGRAWAL, D. and MANN, C. 2010. Factors affecting the valuation of corporate bonds. In: Investments and Portfolio Performance. World Scientific, pp. 53-73.

CHAO, S-W. 2016. Do economic variables improve bond return volatility forecasts? International Review of Economics $\sigma$ Finance, 46: 10-26.

CHO, D. C., EUN, C. S. SENBET, L. W. 1986. International Arbitrage Pricing Theory: An Empirical Investigation. The Journal of Finance, 41(2): 313-329.

CHRISTENSEN, J. H. E. and RUDEBUSCH, G. D. 2012 The Response of Interest Rates to US and UK Quantitative Easing. The Economic Journal, 122(564): F385-F414.

GEAMBASU, C., JIANU, I., HERTELIU, C. and GEAMBASU, L. 2014. Macroeconomic Influence on Shares' return Study Case: Arbitrage Pricing Theory (APT) Applied on Bucharest Stock Exchange. Economic computation and economic cybernetics studies and research / Academy of Economic Studies, 48(2): 1-18.

HUANG, J.-Z. and KONG, W. 2013. Explaining credit spread changes: Some new evidence from option-adjusted spreads of bond indices. Working Paper No. FIN-03-013. Stern School of Business. 
LIU, M.-H., MARGARITIS, D. and TOURANI-RAD, A. 2012. Risk appetite, carry trade and exchange rates. Journal of International Financial Markets, 23(1): 48-63.

LUDVIGSON, S. C. and NG, S. 2009. Macro Factors in Bond Risk Premia. The Review of Financial Studies, 22(12): 5027-5067.

MALHOTRA, K. 2010. Autoregressive multifactor APT model for U.S. Equity Markets. MPRA Paper 23418. MPRA.

MIDDLETON, L. P. and SATCHELL, S. E. 2001. Deriving the Arbitrage Pricing Theory When the Number of Factors Is Unknown. Quantitative Finance, 1(5): 502-508.

PANDA, M. R. and PARIDA, J. K. 2013. A study on asset price fluctuation and the impact of foreign exchange rate on equity pricing. Acta de Gerencia Ciencia, 1(1): 2321-1741.

REZENDE, R. B. 2017. The interest rate effects of government bond purchases away from the lower bound. Journal of International Money and Finance, 74: 165-186.

SERCU, P. A. 1980. Generalization of the international asset pricing model. Revue de I'Association Francaise de Finance, 1: 91-135.

SIRR, G., GARVEY, J. and GALLAGHER, L. 2011. Emerging markets and portfolio foreign exchange risk: An empirical investigation usingthe value-at-risk decomposition technique. Journal of International Money and Finance, 30(8): 1749-1772.

SOLNIK, BRUNO. 1974. Why Not Diversify Internationally Rather than Domestically? Financial Analysts Journal, 30(4): 48-54.

SOLNIK, B. 1983. International Arbitrage Pricing Theory. Journal of Finance, 38(2): 449-457.

VICEIRA, L. M. 2011. Bond risk, bond return volatility, and the term structure of interest rates. International Journal of Forecasting, 28(1): 97-117.

Blanka Francová: xfranco2@mendelu.cz 


\section{APPENDIX}

IV: Definition of analysed variables

\begin{tabular}{|c|c|c|}
\hline Name of variable & Description & Source \\
\hline yield to maturity & Total yield of corporate bond to maturity of bond & Morningstar \\
\hline current yield & Coupon yield of corporate bond & Morningstar \\
\hline capital yield & Capital yield is yield to maturity minus current yield & Morningstar \\
\hline interest rate & Interest rate is the money market rate in the country & International Monetary Fund \\
\hline inflation & Costumer price index & International Monetary Fund \\
\hline exchange rate & Nominal effective exchange rate & World bank \\
\hline Bond yield & Long-term bond yield in the country & International Monetary Fund \\
\hline Risk-free rate & Return of treasury bill in the country & Morningstar \\
\hline bond index & Bond index in the country & Finance yahoo \\
\hline stock index & Stock index in the country & Finance yahoo \\
\hline
\end{tabular}

V: Descriptive statistics

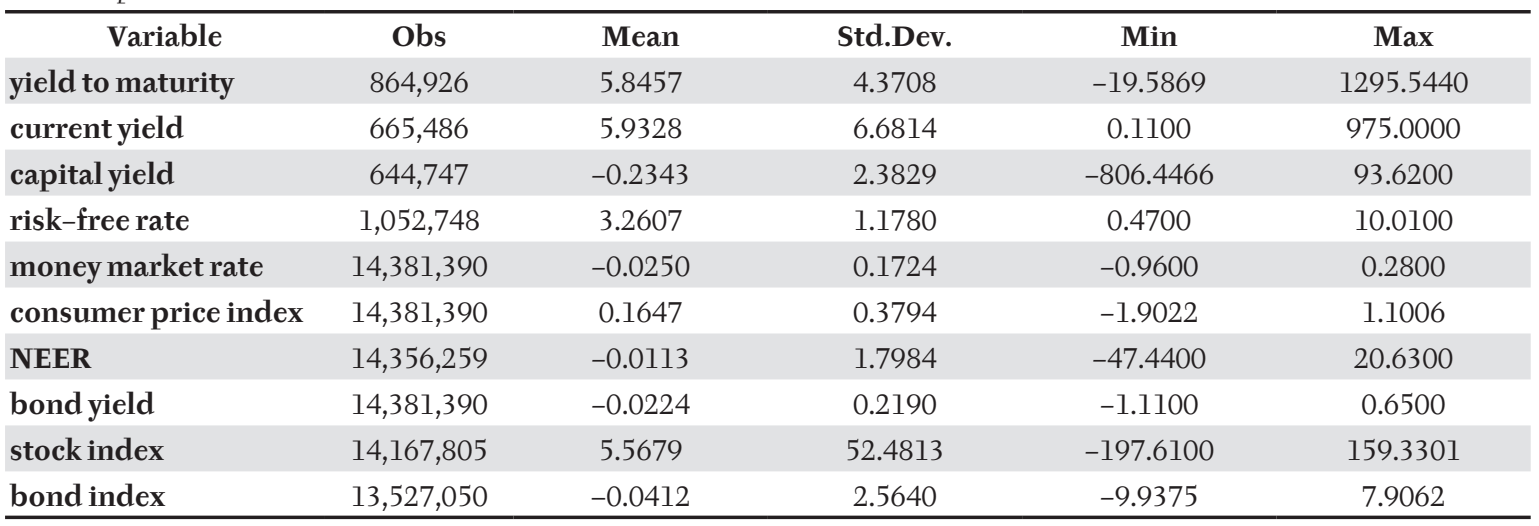

VI: Correlation matrix

\begin{tabular}{|c|c|c|c|c|c|c|c|c|c|}
\hline & $\begin{array}{l}\text { yield to } \\
\text { maturity }\end{array}$ & $\begin{array}{l}\text { current } \\
\text { yield }\end{array}$ & $\begin{array}{l}\text { capital } \\
\text { yield }\end{array}$ & $\begin{array}{l}\text { risk-free } \\
\text { rate }\end{array}$ & $\begin{array}{c}\text { money } \\
\text { market } \\
\text { rate }\end{array}$ & $\begin{array}{l}\text { consumer } \\
\text { price } \\
\text { index }\end{array}$ & NEER & $\begin{array}{l}\text { bond } \\
\text { yield }\end{array}$ & $\begin{array}{l}\text { stock } \\
\text { index }\end{array}$ \\
\hline current yield & 0.6783 & & & & & & & & \\
\hline capital yield & 0.0100 & -0.7280 & & & & & & & \\
\hline risk-free rate & 0.1893 & 0.1179 & 0.0498 & & & & & & \\
\hline money market rate & -0.0673 & -0.0283 & -0.0025 & -0.0558 & & & & & \\
\hline consumer price index & 0.0230 & 0.0157 & -0.0038 & 0.0696 & 0.1797 & & & & \\
\hline NEER & -0.0542 & -0.0404 & -0.0135 & -0.3119 & 0.0206 & -0.0007 & & & \\
\hline bond yield & -0.0100 & -0.0094 & -0.0019 & 0.0058 & 0.0465 & 0.2272 & -0.0238 & & \\
\hline stock index & -0.0306 & -0.0157 & -0.0050 & -0.0450 & 0.1340 & -0.0900 & -0.2696 & 0.1118 & \\
\hline bond index & -0.0070 & -0.0028 & -0.0020 & -0.0170 & 0.0671 & -0.0712 & -0.0190 & -0.0145 & -0.1642 \\
\hline
\end{tabular}

VII: Hausmantest

\begin{tabular}{lccc}
\hline & fixed effects & random effects & difference \\
risk-free rate & 0.513 & 0.537 & -0.024 \\
interest rate & -2.086 & -2.095 & 0.009 \\
inflation & 0.154 & 0.168 & -0.014 \\
exchange rate & 0.016 & 0.016 & 0.001 \\
bond yield & -0.212 & -0.217 & 0.004 \\
bond index & 0.000 & 0.000 & 0.000 \\
stock index & -0.001 & -0.001 & 0.000 \\
\hline
\end{tabular}

Test: Ho: difference in coefficients not systematic

$\operatorname{chi} 2(7)=760.70$

Prob $>$ chi $2=0.000$ 